\title{
Article \\ Acetalization of Glycerol with Citral over Heteropolyacids Immobilized on KIT-6
}

José Castanheiro (D)

check for updates

Citation: Castanheiro, J.

Acetalization of Glycerol with Citra over Heteropolyacids Immobilized

on KIT-6. Catalysts 2022, 12, 81 .

https://doi.org/10.3390/

catal12010081

Academic Editors: Charles Xu and Tianliang Lu

Received: 16 December 2021

Accepted: 9 January 2022

Published: 12 January 2022

Publisher's Note: MDPI stays neutral with regard to jurisdictional claims in published maps and institutional affiliations.

Copyright: (C) 2022 by the author. Licensee MDPI, Basel, Switzerland. This article is an open access article distributed under the terms and conditions of the Creative Commons Attribution (CC BY) license (https:// creativecommons.org/licenses/by/ $4.0 /)$.
MED-Instituto Mediterrâneo Para a Agricultura, Ambiente e Desenvolvimento, Departamento de Química, Escola de Ciências e Tecnologia, Universidade de Évora, 7000-671 Evora, Portugal; jefc@uevora.pt; Tel.: +351-266-745-311

\begin{abstract}
Glycerol acetalization with citral was studied using a heteropolyacid (tungstophosphoric acid) supported on KIT-6, as a catalyst, at $100{ }^{\circ} \mathrm{C}$. Different catalysts were synthesized. Catalysts were characterized by scanning electron microscopy (SEM), inductively coupled plasma (ICP), X-ray diffraction (XRD), attenuated total refletion-Fourier transform infrared spectroscopy (ATR-FTIR), and potentiometric titrations. At a fixed time, the glycerol conversion increased with the $\mathrm{H}_{3} \mathrm{PW}_{12} \mathrm{O}_{40}$ (PW) on KIT-6. PW4-KIT-6 material had a higher conversion than other catalysts. The optimization of glycerol's acetalization with citral was studied under the PW4-KIT-6 catalyst. After $5 \mathrm{~h}$, it was found that, at $\mathrm{T}=100{ }^{\circ} \mathrm{C}$, with $\mathrm{m}=0.3 \mathrm{~g}$ of solid, molar glycerol:citral $=1: 2.25$, the conversion of glycerol was $89 \%$. Moreover, the PW4-KTI-6 catalyst showed good catalytic stability.
\end{abstract}

Keywords: glycerol; citral; heteropolyacids; KIT-6

\section{Introduction}

Due to increased energy consumption and the importance of reducing greenhouse gases, biodiesel production has increased. Biodiesel is a biodegradable, non-toxic, and sulfur-free biofuel. Biodiesel can be produced from vegetable oils, used oils, and animal greases. The reactions involved in the production of biodiesel are transesterification and esterification. These reactions can be performed using $\mathrm{NaOH}, \mathrm{H}_{2} \mathrm{SO}_{4}$, and solid catalysts [1-6]. However, in recent years, the amount of glycerol has increased. It is essential to transform the glycerol into compounds of high commercial value. Different reactions, such as oxidation, esterification, and etherification have been studied [7-11]. Glycerol acetalization with aldehydes and ketones yield acetal compounds, which can be employed in different industries. Acetal compounds obtained from glycerol acetalization are useful fuel additives, fragrances, cosmetics, and pharmaceuticals products [12-23].

Citral is a molecule derived from biomass that is present in bio-oils and available from terpenes and terpenoids. This terpene is an aldehyde, which can be raw material to the fine chemistry industry [24-26]. Glycerol acetalization with citral is a process of valorization of the glycerol and citral, in a circular economy perspective. However, the compounds obtained from the acetalization of glycerol (acetals) can also be used in the fine chemical industry. Therefore, glycerol and citral are molecules with low commercial value that can be transformed into acetals with high commercial value.

Traditionally, the reaction of glycerol with ketones and/or aldehydes was carried out with homogeneous catalysts. However, homogeneous catalysts have some disadvantages, such as difficulty removing from the reaction mixture and reusing. To make this process friendlier to the environment, sulfuric acid was substituted by solid catalysts, such as zeolites, mesostructured silica, and activated carbons [27-29]. Glycerol acetalization with citral was carried out over a mesoporous zirconia catalyst. This material was also utilized in the glycerol acetalization with furfural and cinnamaldehyde [30].

Heteropolyacids (HPAs) are very strong acids and less corrosive than $\mathrm{HCl}$ or $\mathrm{H}_{2} \mathrm{SO}_{4}$. These materials have been used in different reactions as catalysts [31-33]. 
In this work, the reaction of glycerol with citral over $\mathrm{H}_{3} \mathrm{PW}_{12} \mathrm{O}_{40}(\mathrm{PW})$ immobilized on mesostructured silica (KIT-6) is presented. Tungstophosphoric acid is immobilized on KIT-6 during silica synthesis.

\section{Results and Discussion}

\subsection{Catalyst Characterization}

Nitrogen isotherms of the materials are shown in Figure 1. It can be observed that all the materials show isotherms characteristic of KIT-6. The textural characterization of KIT- 6 material and HPW immobilized on KIT-6 are shown in Table 1. It can be observed that surface area $\left(\mathrm{A}_{\mathrm{BET}}\right)$ and porous volume $\left(\mathrm{V}_{\mathrm{P}}\right)$ decreased when the amount of heteropolyacid immobilized on KIT- 6 increased. This behavior could be due to the heteropolyacid immobilized in the framework of KIT-6, which can reduce the surface area to the adsorption sites of the $\mathrm{N}_{2}$ molecules. Guo et al. [34] and Gagea [35] observed that when the heteropolyacids were immobilized on SBA-15, the $\mathrm{A}_{\mathrm{BET}}$ and Vp decreased.

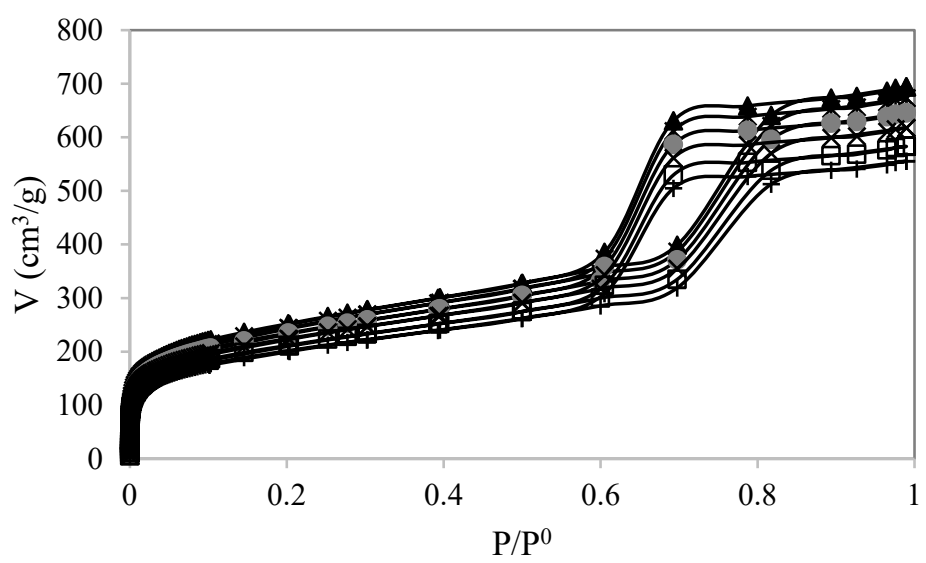

Figure 1. $\mathrm{N}_{2}$ isotherms of materials. (ム) KIT-6; (*) PW1-K-6; (O) PW2-K-6; (×) PW3-K-6; ( $\left.\square\right)$ PW4-K-6; (+) PW5-K-6.

Table 1. Characterization of KIT-6 and KIT-6 (K-6) with heteropolyacid.

\begin{tabular}{cccc}
\hline Materials & HPW Amount $(\mathbf{w t} \%)$ & $\mathbf{A}_{\text {BET }}\left(\mathbf{m}^{\mathbf{2}} \mathbf{g}\right)$ & $\mathbf{V}_{\mathbf{T}} \mathbf{a}\left(\mathbf{c m}^{\mathbf{3}} / \mathbf{g}\right)$ \\
\hline KIT-6 & - & 780 & 0.98 \\
PW1-K-6 & 1.5 & 765 & 0.92 \\
PW2-K-6 & 5.5 & 743 & 0.89 \\
PW3-K-6 & 8.1 & 724 & 0.86 \\
PW4-K-6 & 10.5 & 702 & 0.83 \\
PW5-K-6 & 15.6 & 692 & 0.81 \\
\hline
\end{tabular}

$\mathrm{a}\left(\mathrm{p} / \mathrm{p}^{0}\right)=0.98$.

Figure 2 shows ATR-FTIR spectra of mesostructured silica (KIT-6), tungstophosphoric acid (HPW), and PW4-K-6. The heteropolyacid (HPW) displays principal IR bands, which are situated at 1080, 985, 890, and $839 \mathrm{~cm}^{-1}$ [36]. The main heteropolyacid bands in the ATR-FTIR spectra of PW4-K-6 are indicated in Figure 2. However, some bands characteristic of Keggin units are overlapped with the bands of the KIT-6. In a previous work [37], when HPW was supported on SBA-15, some major bands were also not observed. Moreover, Pizzio et al. [38] observed similar behavior.

Figure 3I displays the XRD of the materials. KIT-6 shows one peak (110) at the $2 \theta$ region of $1^{\circ}$ to $1.2^{\circ}$. All materials with HPW immobilized on KIT-6 show a peak at the $2 \theta$ region. This result may indicate that the mesoporous structure of KIT- 6 is well maintained after the incorporation of HPW into silica. According to Ding et al. [39], the incorporation of molybdophosphoric acid in KIT-6 does not seem to impact the silica structure. 


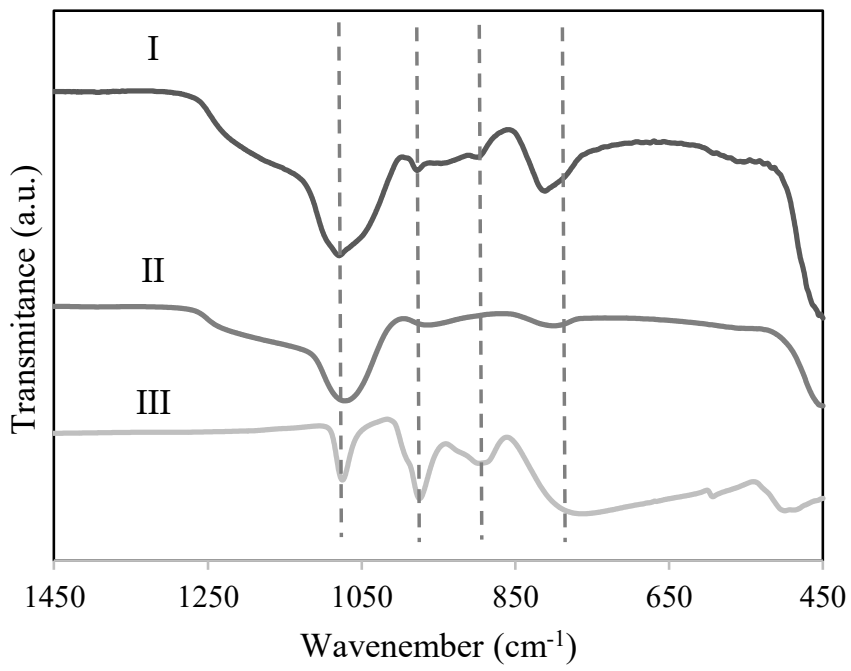

Figure 2. ATR-FTIR spectra of the catalysts: (line I) PW4-K-6; (line II) KIT-6; (line III) PW.
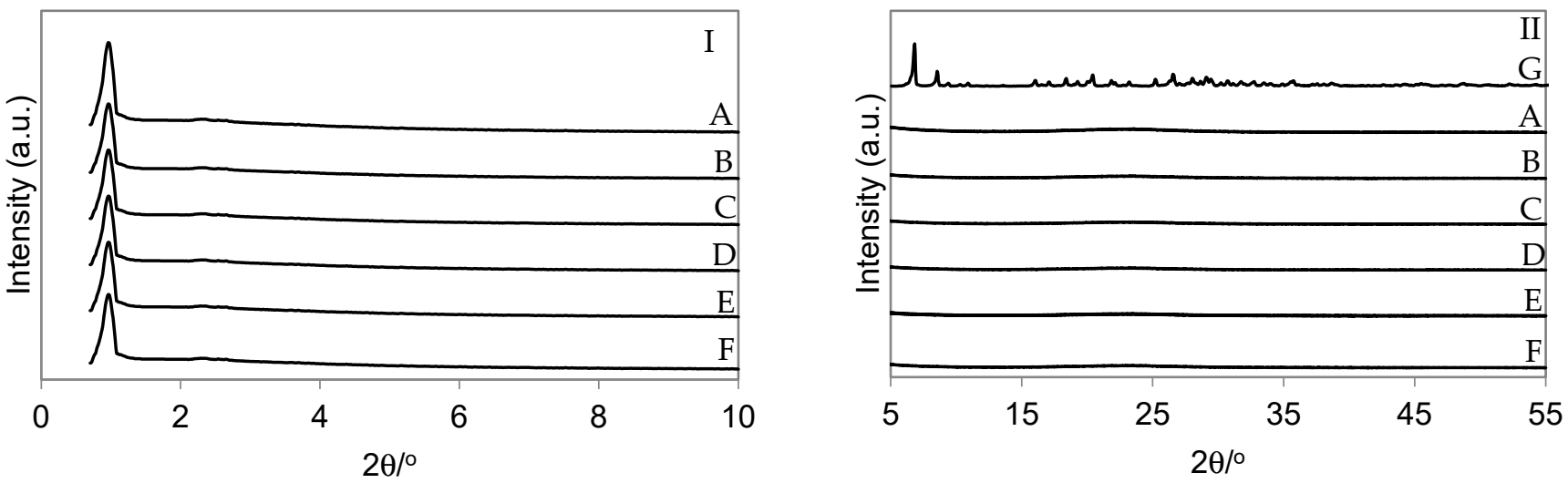

Figure 3. X-ray diffractograms of the catalysts. (I) $2 \theta$ region of $0.7^{\circ}$ to $10.0^{\circ}$; (II) $2 \theta$ region of $5.0^{\circ}$ to $55.0^{\circ}$; (line A) KIT-6; (line B) PW1-K-6; (line C) PW2-K-6; (line D) PW3-K-6; (line E) PW4-K-6; (line F) PW5-K-6; (line G) PW.

Figure $3 \mathrm{II}$ shows the $\mathrm{XRD}$ of the materials at the $2 \theta$ region of $5^{\circ}$ to $55^{\circ}$. It can be observed that peaks characteristic of heteropolyacid (Figure 3II-line G) do not appear on the XRD of KIT- 6 materials. This could be an indication that the particles of PW are extremely well dispersed [36].

Figure 4 displays the TEM images of KIT-6 material (Figure 4I) and PW4-K-6 material (Figure 4II). From the TEM images, the KIT-6 with heteropolyacid (PW4-K-6) apparently shows some variability on the porous system, which is indicated by a white circle. A possible explanation is the interaction between HPW and KIT-6 during their formation process. In previous work, similar results were observed when tungstophosphoric acid was immobilized on SBA-15 [40].

The acidity measurements of KIT- 6 and the materials (PW-K-6) were established by potentiometric titrations with n-butylamine (Figure 5). It determined the Ei (initial electrode potential). The Ei of PW-KIT-6 materials increases with the PW amount supported on mesostructured silica (Table 1), according to the following: $\mathrm{E}_{\mathrm{KIT}-6}=50 \mathrm{mV}<\mathrm{E}_{\mathrm{PW} 1-\mathrm{K}-6}=$ $234 \mathrm{mV}<\mathrm{E}_{\text {PW2-K-6 }}=418 \mathrm{mV}<\mathrm{E}_{\text {PW3-K-6 }}=516 \mathrm{mV}<\mathrm{E}_{\text {PW4-K-6 }}=577 \mathrm{mV}<\mathrm{E}_{\text {PW5-K-6 }}=657 \mathrm{mV}$. This behavior may be due to the increase in the amount of $\mathrm{H}^{+}$with the amount of PW on KIT-6. According to Pizzio et al. [38], when the Ei is greater than $100 \mathrm{mV}$, very strong sites are present on the surface. 

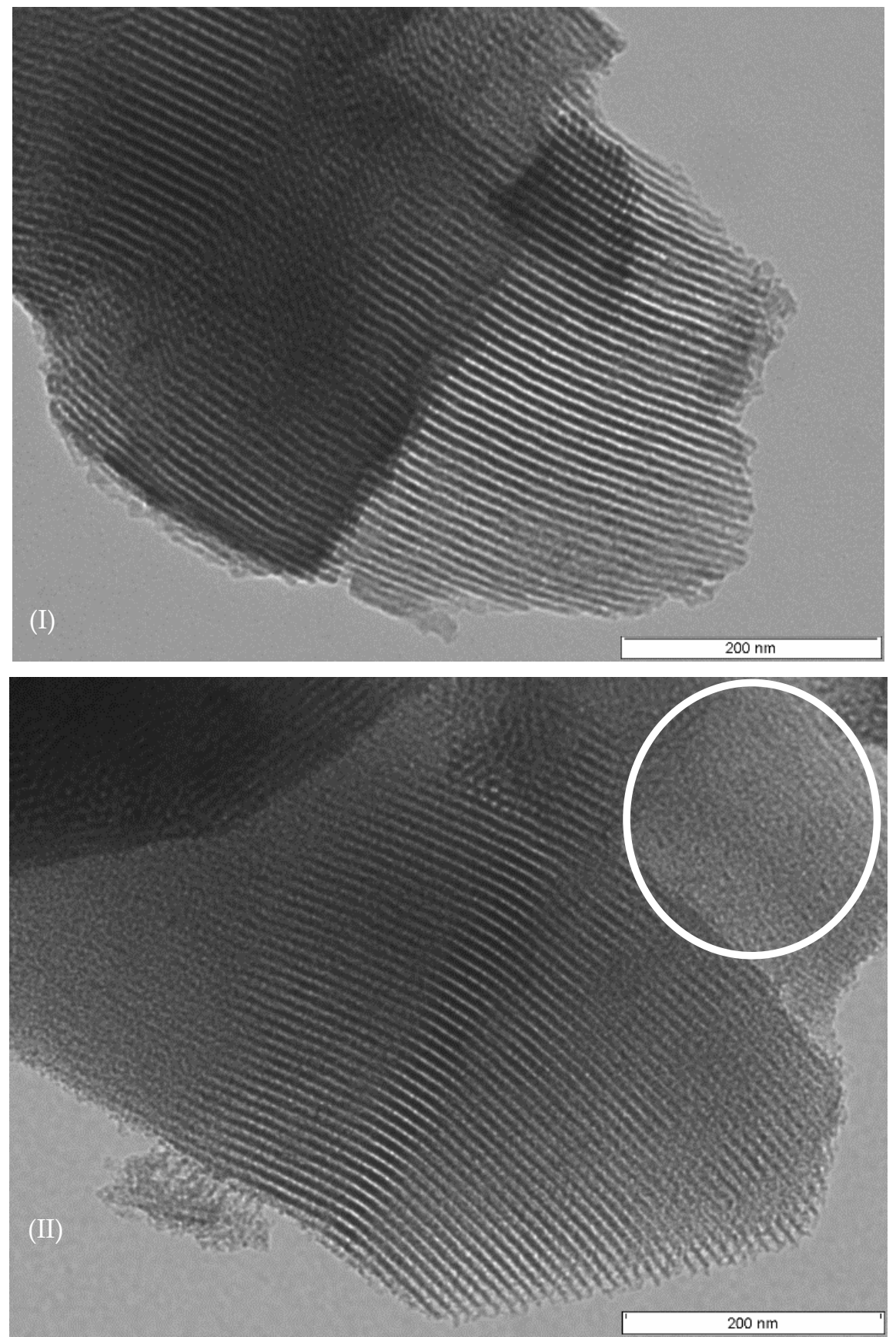

Figure 4. TEM photos: (I) KIT-6; (II) PW4-K-6.

\subsection{Catalytic Experiments}

Glycerol acetalization with citral was performed using heteropolyacids (PW) immobilized on KIT- 6 . Figure 6 exhibits the scheme of glycerol acetalization with citral. The products are (2-(2,6-dimethyl-1,5-heptenyl)-1,3-dioxolan-4-yl)methanol (5R acetal) and 2-(2,6-dimethyl-1,5-heptenyl)-1,3-dioxan-5-ol (6R acetal).

Figure 7 compares the initial activity of KIT-6, PW1-K-6, PW2-K-6, PW3-K-6, PW4-K-6, and PW5-K-6. When the amount of HPW supported on mesostructured silica (KIT-6) increased, the catalytic activity also increased. These results may be due to the increase in the active sites number on KIT- 6 (Table 1). When the amount of heteropolyacid increased from $10.5 \%$ (material PW4-K-6) to $15.6 \%$ (material PW-5-K-6), the catalytic activity of the PW-5-K6 material did not increase. This result may be due to the existence of internal diffusion limitations. In fact, the $\mathrm{S}_{\mathrm{BET}}$ and total porous volume decreased with the amount 
of heteropolyacid supported on KIT-6 (Table 1). It is likely that some active sites present on PW5-K-6 catalysts are not accessible to the reactants. Patel et al. [41] observed the same trend in the glycerol's acetalization with benzaldehyde and furfural over tungstosilicic acid anchored on MCM-48.

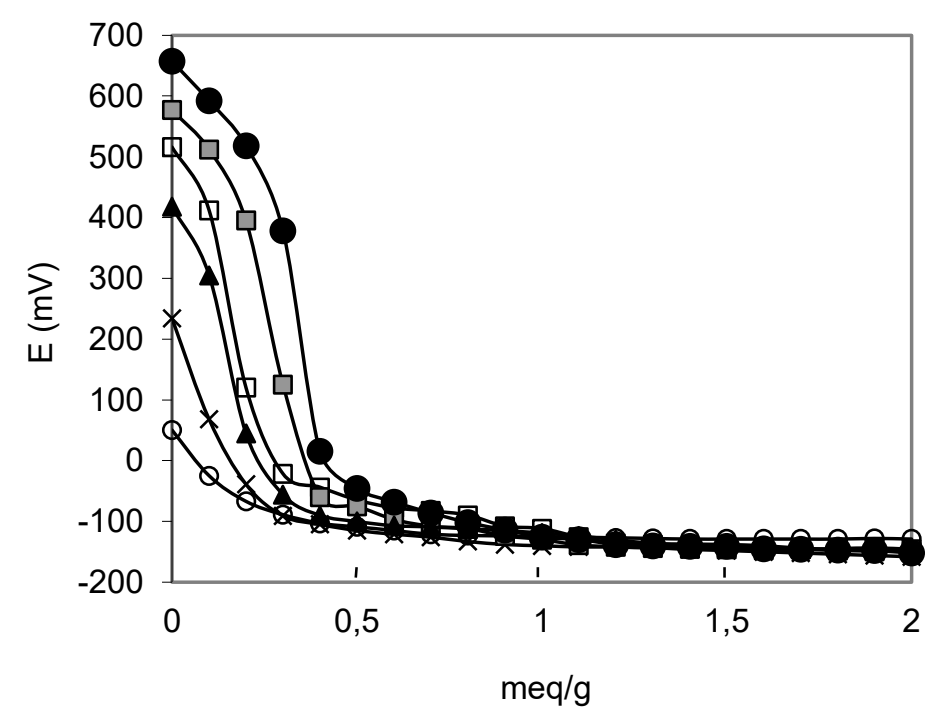

Figure 5. Potentiometric titration of the catalyst. (○) KIT-6; (×) PW1-K-6; (ム) PW2-K-6; ( $\square)$ PW3-K-6; (口) PW4-K-6; (•) PW5-K-6.<smiles>OCC(O)CO</smiles><smiles>CC(C)=CCC/C(C)=C/C=O</smiles><smiles>C=[Tl]</smiles><smiles>[R]C1[C]C(CO)O1</smiles><smiles>[2H]C1OCC(O)C[OH+]1</smiles>

Figure 6. Reaction scheme of acetalization of glycerol with citral, where $\mathrm{R}=-\mathrm{CH}=\mathrm{C}\left(\mathrm{CH}_{3}\right)$ $\mathrm{CH}_{2} \mathrm{CH}_{2} \mathrm{CH}=\mathrm{C}\left(\mathrm{CH}_{3}\right)\left(\mathrm{CH}_{3}\right)$.

Figure 8 exhibits the conversion versus time (h). The glycerol conversion (\%) was 18\% (KIT-6), 46\% (PW1-K-6), 60\% (PW2-K-2), 80\% (PW3-K-6), 89\% (PW4-K-6), and 86\% (PW5-K-6), after $5 \mathrm{~h}$ of reaction.

Selectivity to five- and six-member ring acetal is shown in Table 2. After $5 \mathrm{~h}$ of reaction, the PW4-K-6 catalyst exhibited 75\% selectivity to the $5 \mathrm{R}$ acetal and $25 \%$ to the $6 \mathrm{R}$-acetal at $89 \%$ glycerol conversion. All materials have great selectivity to $5 \mathrm{R}$ acetal, which may be due to the kinetic effects $[16,17,42]$.

Glycerol acetalization with citral was optimized over PW4-K-6 material. The effects of catalyst loading (PW4-K-6), glycerol:citral molar ratio, and temperature of reaction on conversion and selectivity to acetals were studied. 


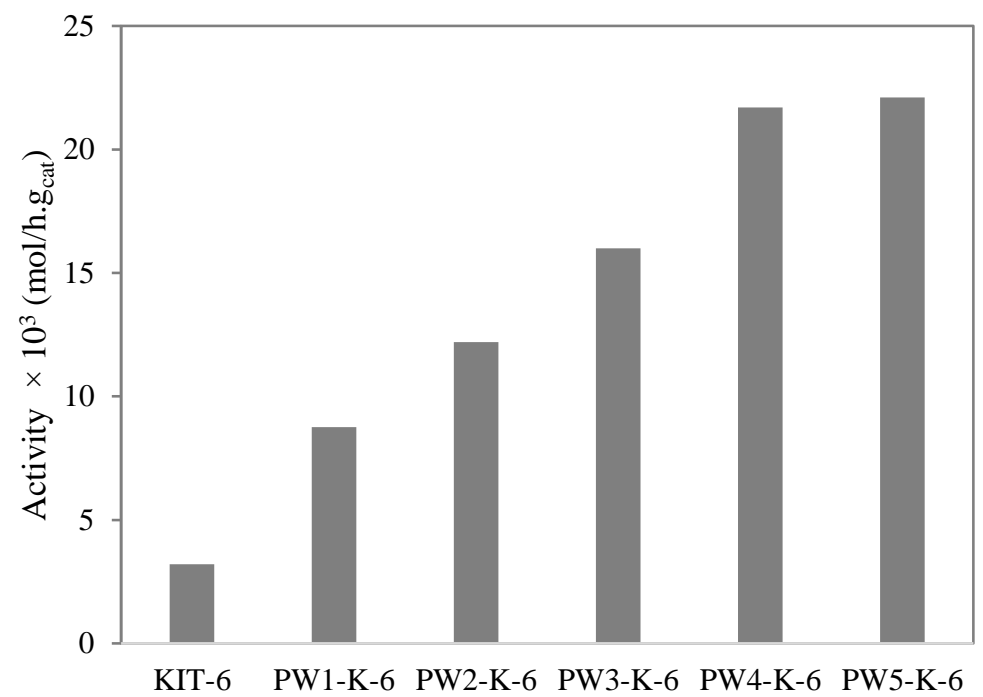

Figure 7. Initial activity of KIT-6 and HPW-K-6 in the acetalization of glycerol with citral.

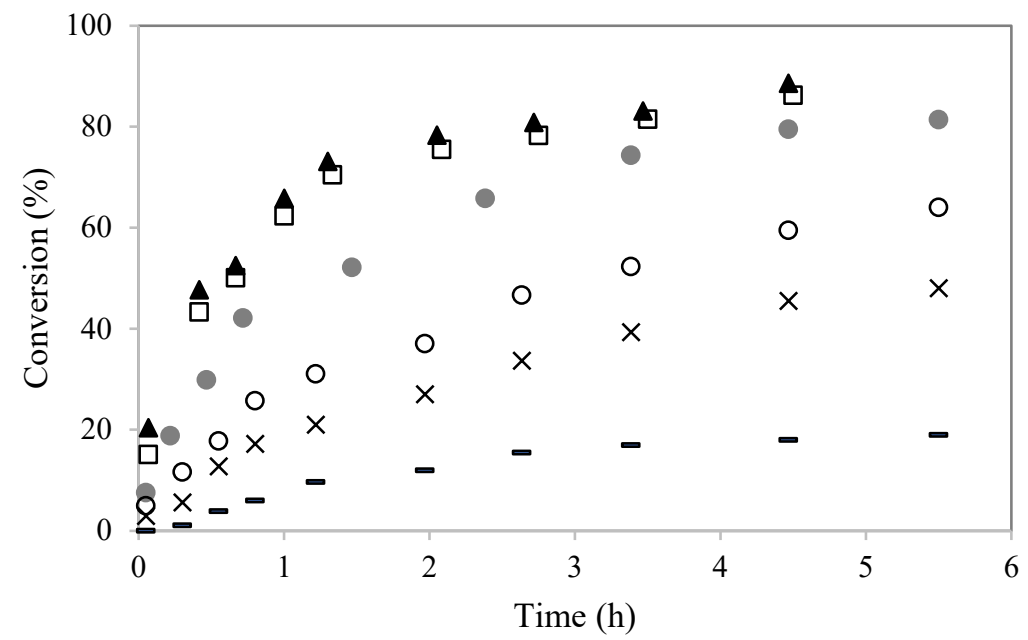

Figure 8. Conversion versus time (h). (-) KIT-6; (×) PW1-K-6; (○) PW2-K-6; (O) PW3-K-6; (ム) PW4-K-6; ( $\square$ ) PW5-K-6.

Table 2. Glycerol conversion and selectivity to five-member ring acetal and six-member ring acetal.

\begin{tabular}{cccc}
\hline \multirow{2}{*}{ Sample } & Conversion $\mathbf{1}^{\mathbf{( \%}} \mathbf{)}$ & \multicolumn{2}{c}{ Selectivity (\%) } \\
\cline { 3 - 4 } & & 5R Acetal & 6R Acetal \\
\hline KIT-6 & 18 & 85 & 15 \\
PW1-K-6 & 46 & 83 & 17 \\
PW2-K-6 & 60 & 82 & 16 \\
PW3-K-6 & 80 & 79 & 21 \\
PW4-K-6 & 89 & 75 & 25 \\
PW5-K-6 & 86 & 75 & 25 \\
\hline
\end{tabular}

${ }^{1}$ After $5 \mathrm{~h}$ of reaction.

\subsection{Catalyst Amount}

The temperature $\left(\mathrm{T}=100{ }^{\circ} \mathrm{C}\right)$ and the glycerol:citral molar ratio (1:2.25) remained constant. The catalyst loading was modified from $0.1 \mathrm{~g}$ to $0.4 \mathrm{~g}$. Figure 9 displays the effects of PW4-K-6 loading on the conversion of glycerol and selectivity to acetal compounds. The conversion of glycerol improved with PW4-K-6 loading. This behavior may be justified by the rise in the number of sites in the reactor. The selectivity to $5 \mathrm{R}$ acetal and $6 \mathrm{R}$ acetal 
were also analyzed. The selectivity to $5 \mathrm{R}$ acetal was $87 \%$ (at $67 \%$ conversion), $80 \%$ (at $77 \%$ conversion), 75\% (at 89\% conversion), and 72\% (at 96\% conversion) using $0.10 \mathrm{~g}, 0.20 \mathrm{~g}$, $0.30 \mathrm{~g}$, and $0.40 \mathrm{~g}$ of PW4-K-6, respectively, after $5 \mathrm{~h}$. It appears that the selectivity to the $5 \mathrm{R}$ acetal did not change much with the material loading $[43,44]$, but a slight decrease in selectivity (5R acetal) was observed.

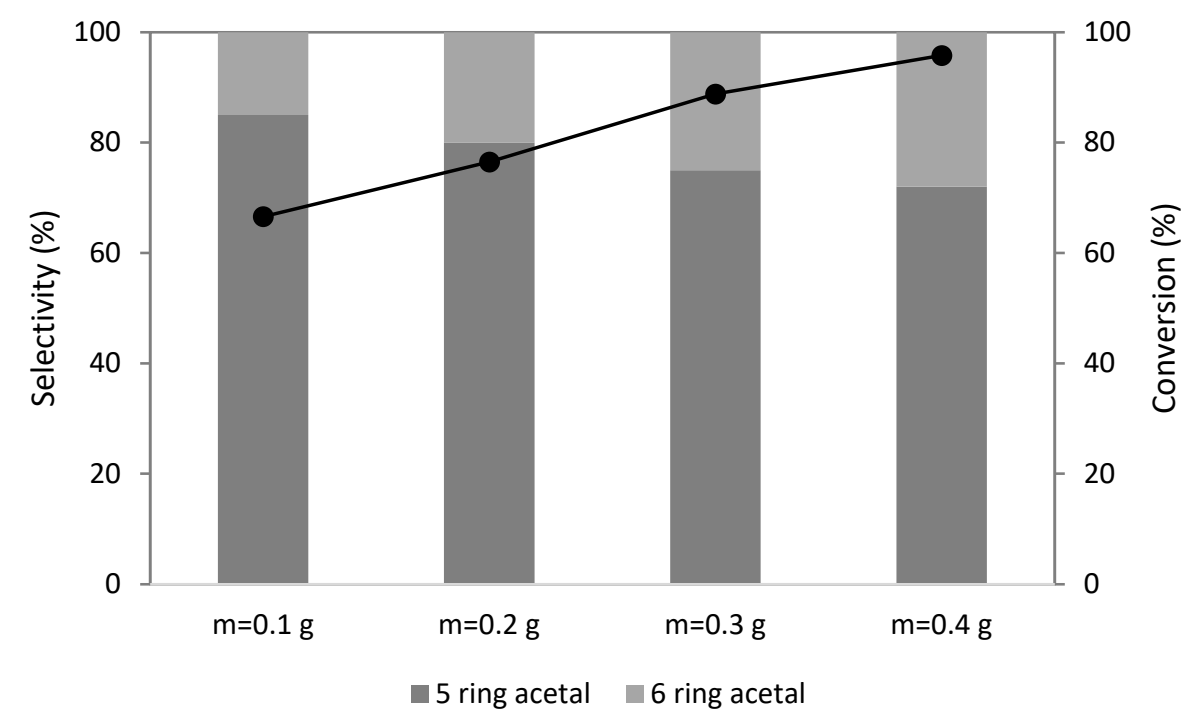

Figure 9. Acetalization of glycerol with citral over PW4-K-6. Effect of catalyst amount after $5 \mathrm{~h}$ of reaction.

\subsection{Temperature}

The amount of PW4-K-6 material (0.3 g) and the molar ratio of glycerol:citral (1:2.25) remained constant. The temperature ranged between $80^{\circ} \mathrm{C}$ to $120^{\circ} \mathrm{C}$. Glycerol conversion increased with temperature (Figure 10). After $5 \mathrm{~h}$, the selectivity to the $5 \mathrm{R}$ acetal was $86 \%$ (at $63 \%$ conversion), $81 \%$ (at $75 \%$ conversion), $75 \%$ (at $89 \%$ conversion), and $72 \%$ (at $94 \%$ conversion) at $\mathrm{T}=80^{\circ} \mathrm{C}, \mathrm{T}=90^{\circ} \mathrm{C}, \mathrm{T}=100{ }^{\circ} \mathrm{C}$, and $\mathrm{T}=120{ }^{\circ} \mathrm{C}$, respectively. As the synthesis of the $5 R$ acetal is easier than $6 R$ acetal $[43,44]$, selectivity to the $5 R$ acetal did not change substantially when the temperature increased (decreased about $10 \%$ ). This decrease could be due to the isomerization reaction [45].

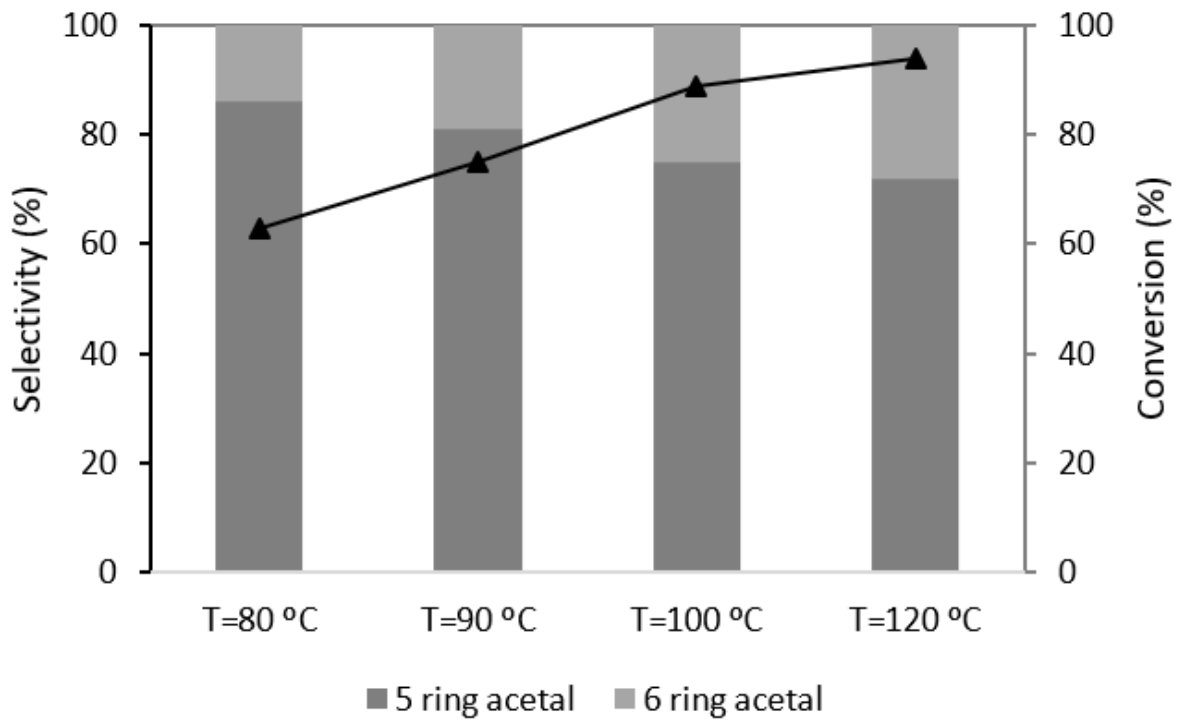

Figure 10. Acetalization of glycerol with citral over PW4-K-6. Effect of the temperature. 


\subsection{Glycerol: Citral Molar Ratio}

The study of the glycerol:citral molar ratio in the glycerol conversion was performed using PW4-K-6 material. The molar ratios of 1:1, 1:2.25, and 1:5.1 were studied, while the temperature $\left(\mathrm{T}=100{ }^{\circ} \mathrm{C}\right)$ and catalyst loading $(\mathrm{m}=0.30 \mathrm{~g})$ were maintained. The conversion of glycerol increased with the increase in the molar ratio (from 1:1 to 1:2.25). However, the glycerol conversion did not improve when increasing the molar ratio from 1:2.25 to 1:5.1 (Figure 11). This behavior may be due to the occupation of citral molecules over the active positions of material. A large amount of aldehyde impedes the reaction [43].

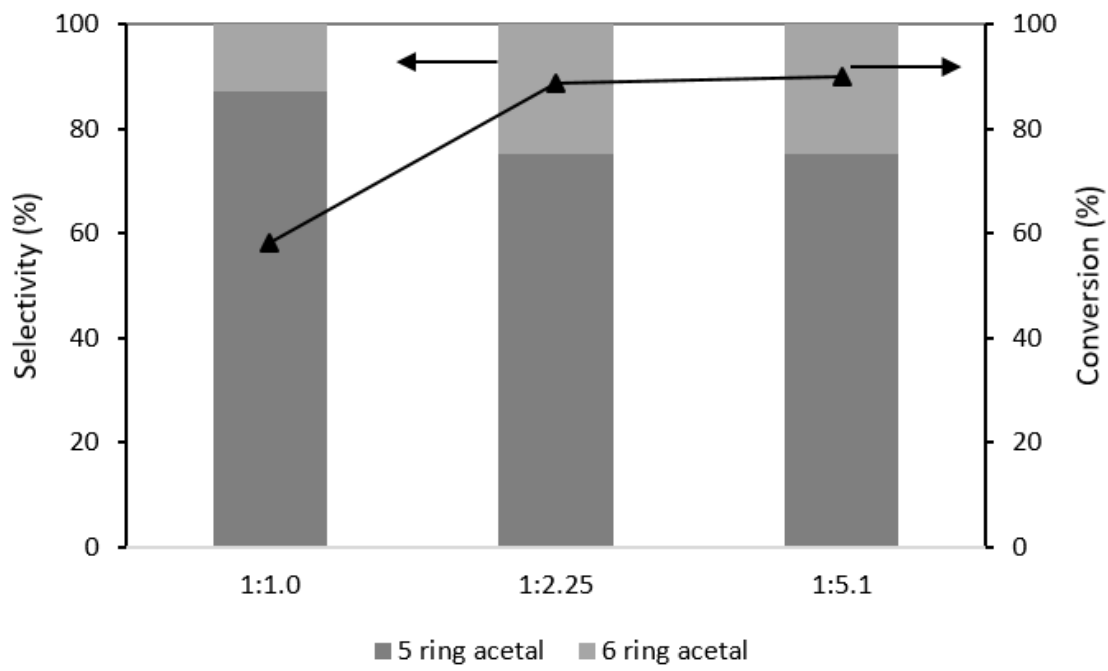

Figure 11. Acetalization of glycerol with citral over PW4-K-6. Effect of glycerol:citral molar ratio, after $5 \mathrm{~h}$ of reaction.

The selectivity obtained, after $5 \mathrm{~h}$, to the $5 \mathrm{R}$ acetal was $87 \%$ (at $58 \%$ glycerol conversion), $75 \%$ (at $89 \%$ glycerol conversion), and 75\% (at 90\% glycerol conversion) at ratios of $1: 1$, $1: 2.25$, and 1:5.1, respectively.

PW4-K-6 was reused. Different experiments were performed using PW4-K-6 material. Figure 12 indicates the activity of PW4-K-6 achieved. The activity of PW4-K-6 material is great after the fifth utilization. The HPW amount present on the KIT- 6 solid was obtained by ICP. The catalyst lost $3 \%$ of HPW present on KIT- 6 .

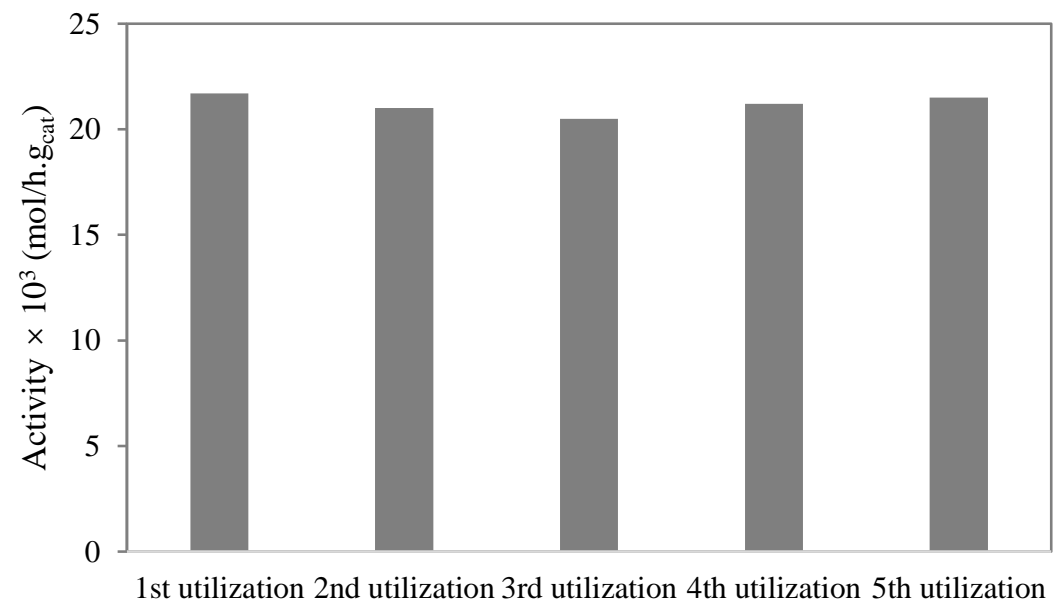

Figure 12. Stability of PW4-K-6 material.

Great selectivity to 5R acetal was obtained after the fifth utilization of PW4-K-6 (Table 3). 
Table 3. Conversion of glycerol and selectivity to $5 \mathrm{R}$ acetal and $6 \mathrm{R}$ acetal.

\begin{tabular}{cccc}
\hline \multirow{2}{*}{ Sample } & Conversion ${ }^{\mathbf{1}} \mathbf{( \% )}$ & \multicolumn{2}{c}{ Selectivity (\%) } \\
\cline { 3 - 4 } & & 5R Acetal & 6R Acetal \\
\hline 1st utilization & 89 & 75 & 25 \\
2nd utilization & 87 & 76 & 24 \\
3rd utilization & 88 & 76 & 24 \\
4th utilization & 87 & 76 & 24 \\
5th utilization & 88 & 76 & 24 \\
\hline
\end{tabular}

${ }^{1}$ After $5 \mathrm{~h}$ of reaction.

The glycerol acetalization with citral may be triggered by interactions between the oxygen atom of the carbonyl group of citral (aldehyde) and Brönsted acid sites, according to the mechanistic proposal given in Figure $13[18,41]$. Specifically, the formation of a hemiacetal in the reaction of the citral with glycerol may be followed by the elimination of an $\mathrm{H}_{2} \mathrm{O}$ molecule and formation of a carbocation [41], which, in turn, suffers an attack involving the inner or terminal hydroxyl group of the glycerol molecule, finally giving the cyclic acetals 1,3-dioxolane and 1,3-dioxane, respectively.

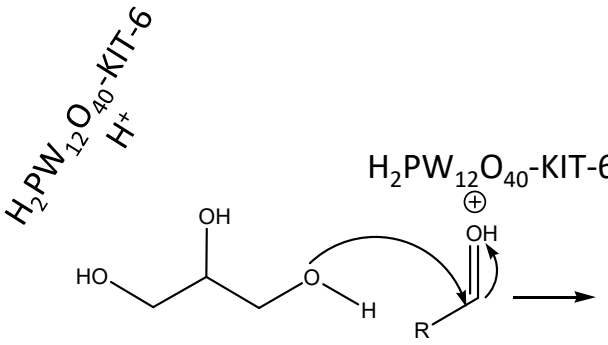<smiles>[R]C1ON=C(CC(O)CO)O1</smiles><smiles>[R]C(OCC)OCC(O)CO</smiles>

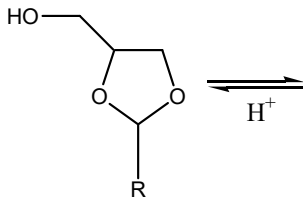

1,3-dioxolane<smiles>[2H]OCC(COCC)OCC</smiles><smiles>OC1COC(P)O1</smiles>

1,3-dioxane

Figure 13. Mechanistic proposal exemplified for the glycerol acetalization with citral over PW4-K-6, leading to the 1,3-dioxolane or 1,3-dioxane acetal products (where $\mathrm{R}=-\mathrm{CH}=\mathrm{C}\left(\mathrm{CH}_{3}\right)$ $\left.\mathrm{CH}_{2} \mathrm{CH}_{2} \mathrm{CH}=\mathrm{C}\left(\mathrm{CH}_{3}\right)\left(\mathrm{CH}_{3}\right)\right)$. 
The PW4-K-6 activity for the glycerol acetalization with citral was evaluated with the activity of other materials described in the literature. Table 4 indicates the activity of the materials. The activity (expressed as $\mathrm{h}^{-1}$ ) of the PW4-K-6, $\mathrm{ZrO}_{2}-350$, and PW4-SBA-15 materials was found to increase as follows: $5.2 \mathrm{~h}^{-1}$ (obtained with $\mathrm{ZrO}_{2}-350$, [30]) $<489 \mathrm{~h}^{-1}$ (obtained over PW4-SBA-15 [present work]) $<596 \mathrm{~h}^{-1}$ (obtained over PW4-K-6 [present work]). The PW4-K-6 catalyst showed high catalytic activity.

Table 4. Comparison of the results for acetalization of glycerol with literature data for other solid acid catalysts.

\begin{tabular}{cccccc}
\hline Catalyst & 5R Acetal & 6R Acetal & Conversion (\%) & Activity (h $^{-\mathbf{1}}$ ) & Reference \\
\hline $\mathrm{ZrO}_{2}-350^{\mathrm{a}}$ & 29 & 46 & 64 & 5.2 & {$[30]$} \\
$\mathrm{PW} 4-\mathrm{K}-6^{\mathrm{b}}$ & 75 & 25 & 89 & 596 & Present work \\
PW4-SBA-15 ${ }^{\mathrm{b}, \mathrm{c}}$ & 76 & 24 & 86 & 489 & Present work \\
\hline
\end{tabular}

a Reaction conditions: $3.75 \times 10^{-3} \mathrm{~mol}$ citral, $48 \times 10^{-3}$ mol glycerol, $0.4 \mathrm{~g}$ catalyst, $100{ }^{\circ} \mathrm{C}, 4 \mathrm{~h}$. ${ }^{\mathrm{b}}$ Reaction conditions: $90 \times 10^{-3} \mathrm{~mol}$ citral, $48 \times 10^{-3} \mathrm{~mol}$ glycerol, $0.3 \mathrm{~g}$ catalyst, $100^{\circ} \mathrm{C}, 5 \mathrm{~h}$. ${ }^{\mathrm{c}} \mathrm{PW} 4-\mathrm{SBA}-15$ prepared according to previous work [6].

\section{Materials and Methods}

\subsection{Materials}

Template (Pluronic P-123), 1-butanol (99.8\%), citral (96\%), dioxane (99\%), tetraethylorthosilicate (TEOS), $\mathrm{HCl}$ (37\%), tungstophosphoric acid, and glycerol (99\%) were acquired to Sigma-Aldrich.

\subsection{Preparation of Catalysts}

The KIT-6 material was synthesized according to Pirez et al. [46]. Briefly, $4 \mathrm{~g}$ of Pluronic P123 were dispersed in $144 \mathrm{~mL}$ of distilled $\mathrm{H}_{2} \mathrm{O}$, and $7.9 \mathrm{~g}$ of $35 \% \mathrm{HCl}$ was added to the mixture, under stirring at $35^{\circ} \mathrm{C}$. After complete dissolution, $4 \mathrm{~g}$ of 1-butanol was added. The mixture was stirred for $1 \mathrm{~h}$. After this period, $8.6 \mathrm{~g}$ of tetraethylorthosilicate (TEOS) was added. The solution then remained under stirring at $35^{\circ} \mathrm{C}$ for $24 \mathrm{~h}$. At the end of this period, the solution was placed in a closed autoclave and heated at $100{ }^{\circ} \mathrm{C}$ for $24 \mathrm{~h}$. The precipitate was filtered and dried in an oven at $100{ }^{\circ} \mathrm{C}$ for $24 \mathrm{~h}$. Finally, the fine powder obtained was washed (ethanol and $\mathrm{HCl}$ mixture) and calcined in air at $550{ }^{\circ} \mathrm{C}$.

Heteropolyacid $\left(\mathrm{H}_{3} \mathrm{PW}_{12} \mathrm{O}_{40}\right)$ immobilization was prepared by direct synthesis. The first steps of the synthesis were like the steps described by Pirez et al. [45]. The difference in the synthesis material was in the step where TEOS was added. Thus, $8.6 \mathrm{~g}$ of TEOS and the required amounts of $\mathrm{H}_{3} \mathrm{PW}_{12} \mathrm{O}_{40}$ in $\mathrm{CH}_{3} \mathrm{CH}_{2} \mathrm{OH}$ solution were added to the mixture. This mixture was stirred for $24 \mathrm{~h}$. After this period, the mixture was put in an autoclave. This reactor was heated at $100{ }^{\circ} \mathrm{C}$ for $24 \mathrm{~h}$. After this period, the solid obtained was treated according to previous work [6].

\subsection{Materials Characterization}

$\mathrm{A}_{\mathrm{BET}}$ and total volume porous $(\mathrm{Vp})$ of materials were calculated from $\mathrm{N}_{2}$ isotherms at $77 \mathrm{~K}$ using a Micromeritics ASAP 2010.

The amount of HPW supported in KIT-6 was analyzed by ICP.

The ATR-FTIR spectra were obtained using a Perkin Elmer Spectrum 100 FTIR spectrophotometer.

XRD patterns of HPW, KIT-6, and PW-K-6 materials were acquired using a Rigaku Miniflex powder diffractometer.

TEM photos were executed on a Hitachi S-2400 instrument.

The potentiometric titration was determined according to Pizzio et al. [38].

\subsection{Catalytic Experiments}

The reactions were performed using a stirred batch reactor at $100{ }^{\circ} \mathrm{C}$. In a typical reaction, $0.09 \mathrm{~mol}$ of citral, $0.04 \mathrm{~mol}$ of glycerol, and $0.3 \mathrm{~g}$ catalyst were added to the reactor. 
The catalyst PW4-KIT-6 was reused.

The internal standard used was Dioxane.

Some samples were removed from the batch reactor and analyzed with a GC (a Hewlett Packard instrument), using the analysis conditions reported in previous work [19].

\section{Conclusions}

KIT- 6 occluded $\mathrm{H}_{3} \mathrm{PW}_{12} \mathrm{O}_{40}$ was prepared and applied, as a catalyst, on glycerol acetalization with citral. Materials with different HPW amounts (1.5 to $15.3 \mathrm{wt} . \%$ ) in KIT-6 were synthesized. The PW4-K-6 catalyst (with $10.5 \mathrm{wt} . \%$ ) showed higher activity than other KIT-6 materials.

All the materials exhibited great selectivity to the $5 \mathrm{R}$ acetal.

The catalytic stability of PW4-K-6 material was studied. After the fifth use, the material showed great conversion.

Funding: This research received no external funding.

Data Availability Statement: The compound used for the catalysis and raw characterization data studies herein reported are available from the authors upon request.

Conflicts of Interest: The authors declare no conflict of interest.

\section{References}

1. Alsultan, A.G.; Asikin-Mijan, N.; Ibrahim, Z.; Yunus, R.; Razali, S.Z.; Mansir, N.; Islam, A.; Seenivasagam, S.; Taufiq-Yap, Y.H. A Short Review on Catalyst, Feedstock, Modernised Process, Current State and Challenges on Biodiesel Production. Catalysts 2021, 11, 1261. [CrossRef]

2. Avhad, M.R.; Marchetti, J.M. Innovation in solid heterogeneous catalysis for the generation of economically viable and ecofriendly biodiesel: A review. Catal. Rev. 2016, 58, 157-208. [CrossRef]

3. Lotero, E.; Liu, Y.; Lopez, D.E.; Suwannakarn, K.; Bruce, D.A.; Goodwin, J.G. Synthesis of biodiesel via acid catalysis. Ind. Eng. Chem. Res. 2005, 44, 5353-5363. [CrossRef]

4. Avhad, M.R.; Marchettin, J.M. A review on recent advancement in catalytic materials for biodiesel production. Renew. Sust. Energ. Rev. 2015, 50, 696-718. [CrossRef]

5. Singh, S.; Patel, A. 12-Tungstophosphoric acid supported on mesoporous molecular material: Synthesis, characterization and performance in biodiesel production. J. Clean. Prod. 2014, 72, 46-56. [CrossRef]

6. Castanheiro, J.E.; Fonseca, I.M.; Ramos, A.M.; Vital, J. Tungstophosphoric acid immobilised in SBA-15 as an efficient heterogeneous acid catalyst for the conversion of terpenes and free fatty acids. Micropor. Mesopor. Mat. 2017, 249, 16-24. [CrossRef]

7. Smirnov, A.A.; Selishcheva, S.A.; Yakovlev, V.A. Acetalization catalysts for synthesis of valuable oxygenated fuel additives from glycerol. Catalysts 2018, 8, 595. [CrossRef]

8. Natalia, B.; Thomas, R.; Martin, K.; Stephan, A.S. Valorisation of Glycerol as Renewable Feedstock: Comparison of the Exploration of Chemical Transformation Methods Aided by High Throughput Experimentation. Comb. Chem. High. Throughput Screen. 2012, $15,123-135$.

9. Rodrigues, A.; Bordado, J.C.; dos Santos, R.G. Upgrading the Glycerol from Biodiesel Production as a Source of Energy Carriers and Chemicals-A Technological Review for Three Chemical Pathways. Energies 2017, 10, 1817. [CrossRef]

10. Rahmat, N.; Abdullah, A.Z.; Mohamed, A.R. Recent progress on innovative and potential technologies for glycerol transformation into fuel additives: A critical review. Renew. Sustain. Energy Rev. 2010, 14, 987-1000. [CrossRef]

11. Checa, M.; Nogales-Delgado, S.; Montes, V.; Encinar, J.M. Recent Advances in Glycerol Catalytic Valorization: A Review. Catalysts 2020, 10, 1279. [CrossRef]

12. Mallesham, B.; Sudarsanam, P.; Reddy, B.M. Eco-friendly synthesis of bio-additive fuels from renewable glycerol using nanocrystalline $\mathrm{SnO}_{2}$-based solid acids. Catal. Sci. Technol. 2014, 4, 803-881. [CrossRef]

13. Kundu, S.K.; Singuru, R.; Hayashi, T.; Hijikata, Y.; Irle, S.; Mondal, J. Constructing sulfonic acid functionalized anthracene derived conjugated porous organic polymer for efficient metal-free catalytic acetalization of bio-Glycerol. ChemistrySelect 2017, 2, 4705-4716. [CrossRef]

14. Konwar, L.J.; Samikannu, A.; Mäki-Arvela, P.; Boström, D.; Mikkola, J.-P. Lignosulfonate-based macro/mesoporous solid protonic acids for acetalization of glycerol to bio-additives. Appl. Catal. B Environ. 2018, 220, 314-323. [CrossRef]

15. Gonzalez-Arellano, C.; Arancon, R.A.D.; Luque, R. Al-SBA-15 catalysed cross-esterification and acetalisation of biomass-derived platform chemicals. Green Chem. 2014, 16, 4985-4993. [CrossRef]

16. Serafim, H.; Fonseca, I.M.; Ramos, A.M.; Vital, J.; Castanheiro, J.E. Valorization of glycerol into fuel additives over zeolites as catalysts. Chem. Eng. J. 2011, 178, 291-296. [CrossRef]

17. Silva, P.H.R.; Gonçalves, V.L.C.; Mota, C.J.A. Glycerol acetals as anti-freezing additives for biodiesel. Bioresour. Technol. 2010, 101, 6225-6229. [CrossRef] 
18. Antunes, M.M.; Mendes, R.F.; Paz, F.A.A.; Valente, A.A. Versatile Coordination Polymer Catalyst for Acid Reactions Involving Biobased Heterocyclic Chemicals. Catalysts 2021, 11, 190. [CrossRef]

19. Castanheiro, J.E.; Vital, J.; Fonseca, I.M.; Ramos, A.M. Acetalization of glycerol with hexanal in the presence of SBA-15 with sulfonic acid groups. Catal. Today 2022, 484-386, 2-11. [CrossRef]

20. Climent, M.J.; Corma, A.; Velty, A. Synthesis of hyacinth, vanilla, and blossom orange fragrances: The benefit of using zeolites and delaminated zeolites as catalysts. Appl. Catal. A Gen. 2004, 263, 155-161. [CrossRef]

21. Castanheiro, J.E.; Vital, J.; Fonseca, I.M.; Ramos, A.M. Glycerol conversion into biofuel additives by acetalization with pentanal over heteropolyacids immobilized on zeolites. Catal. Today 2020, 346, 76-80. [CrossRef]

22. Deutsch, J.; Martin, A.; Lieske, H. Investigations on heterogeneously catalysed condensations of glycerol to cyclic acetals. J. Catal. 2007, 245, 428-435. [CrossRef]

23. Lopes, N.F.; Caiado, M.; Canhao, P.; Castanheiro, J.E. Synthesis of bio-fuel additives from glycerol over poly(vinyl Alcohol) with sulfonic acid groups. Energy Sources A: Recovery Util. Environ. Eff. 2015, 37, 1928-1936. [CrossRef]

24. Corma, A.; Iborra, S.; Velty, A. Chemical routes for the transformation of biomass into chemicals. Chem. Rev. 2007, 107, 2411-2502. [CrossRef] [PubMed]

25. Wu, L.; Moteki, T.; Gokhale, A.A.; Flaherty, D.W.; Toste, F.D. Production of fuels and chemicals from biomass: Condensation reactions and beyond. Chem 2016, 1, 32-58. [CrossRef]

26. Bruneau, C.; Fischmeister, C.; Mandelli, D.; Carvalho, W.A.; dos Santos, E.N.; Dixneuf, P.H.; Fernandes, L.S. Transformations of terpenes and terpenoids via carbon-carbon double bond metathesis. Catal. Sci. Technol. 2018, 8, 3989-4004. [CrossRef]

27. Vannucci, J.A.; Nichio, N.N.; Pompeo, F. Solketal synthesis from ketalization of glycerol with acetone: A kinetic study over a sulfated zirconia catalyst. Catal. Today 2021, 372, 238-245. [CrossRef]

28. Melero, J.A.; van Grieken, R.; Morales, G.; Paniagua, M. Acidic Mesoporous Silica for the Acetylation of Glycerol: Synthesis of Bioadditives to Petrol Fuel. Energy Fuel 2007, 21, 1782-1791. [CrossRef]

29. Narkhede, N.; Patel, A. Room temperature acetalization of glycerol to cyclic acetals over anchored silicotungstates under solvent free conditions. RSC Adv. 2014, 4, 19294-19301. [CrossRef]

30. Akinnawo, C.A.; Mosia, L.; Alimi, O.A.; Oseghale, C.O.; Fapojuwo, D.P.; Bingwa, N.; Meijboom, R. Eco-friendly synthesis of valuable fuel bio-additives from glycerol. Catal. Commun. 2021, 152, 106287. [CrossRef]

31. Kozhevnikov, I.V. Catalysis by Heteropoly Acids and Multicomponent Polyoxometalates in Liquid-Phase Reactions. Chem. Rev. 1998, 98, 171-198. [CrossRef]

32. Sanchez, L.M.; Thomas, H.J.; Climent, M.J.; Romanelli, G.P.; Iborra, S. Heteropolycompounds as catalysts for biomass product transformations. Catal. Rev. 2016, 58, 497-586. [CrossRef]

33. Patel, A.; Narkhede, N.; Singh, S.; Pathan, S. Keggin-type lacunary and transition metal substituted polyoxometalates as heterogeneous catalysts: A recent progress. Catal. Rev. 2016, 58, 337-370. [CrossRef]

34. Guo, Y.; Li, K.; Yu, X.; Clark, J.H. Mesoporous $\mathrm{H}_{3} \mathrm{PW}_{12} \mathrm{O}_{40}$-silica composite: Efficient and reusable solid acid catalyst for the synthesis of diphenolic acid from levulinic acid. Appl. Catal. B Env. 2008, 81, 182-191. [CrossRef]

35. Gagea, B.C.; Lorgouilloux, Y.; Altintas, Y.; Jacobs, P.A.; Martens, J.A. Bifunctional conversion of n-decane over HPW heteropoly acid incorporated into SBA-15 during synthesis. J. Catal. 2009, 265, 99-108. [CrossRef]

36. Chai, S.-H.; Wang, H.-P.; Liang, Y.; Xu, B.-Q. Sustainable production of acrolein: Gas-phase dehydration of glycerol over 12-tungstophosphoric acid supported on $\mathrm{ZrO}_{2}$ and $\mathrm{SiO}_{2}$. Green Chem. 2008, 10, 1087-1093. [CrossRef]

37. Chen, L.; Nohair, B.; Zhao, D.; Kaliaguine, S. Glycerol acetalization with formaldehyde using heteropolyacid salts supported on mesostructured silica. Appl. Catal. A Gen. 2018, 549, 207-215. [CrossRef]

38. Pizzio, L.R.; Vásquez, P.G.; Cáceres, C.V.; Blanco, M.N. Supported Keggin type heteropolycompounds for ecofriendly reactions. Appl. Catal. A Gen. 2003, 256, 125-139. [CrossRef]

39. Ding, Y.; Wang, J.; Liao, M.; Li, J.; Zhang, L.; Guo, J.; Wu, H. Deep oxidative desulfurization of dibenzothiophene by novel POM-based IL immobilized on well-ordered KIT-6. Chem. Eng. J. 2021, 418, 129470. [CrossRef]

40. Sheng, X.; Kong, J.; Zhou, Y.; Zhang, Y.; Zhang, Z.; Zhou, S. Direct synthesis, characterization and catalytic application of SBA-15 mesoporous silica with heteropolyacid incorporated into their framework. Micropor. Mesopor. Mater. 2014, 187, 7-13. [CrossRef]

41. Patel, A.; Pithadia, D. Low temperature synthesis of bio-fuel additives via valorization of glycerol with benzaldehyde as well as furfural over a novel sustainable catalyst, 12-tungstosilicic acid anchored to ordered cubic nano-porous MCM-48. Appl. Catal. A Gen. 2020, 602, 117729. [CrossRef]

42. Wang, B.; Shen, Y.; Sun, J.; Xu, F.; Sun, R. Conversion of platform chemical glycerol to cyclic acetals promoted by acidic ionic liquids. RSC Adv. 2014, 36, 18917-18923. [CrossRef]

43. Aksnes, G.; Albriktsen, P.; Juvvik, P.; Thelin, H.; Sjoberg, B.; Larsen, E. Studies of Cyclic Acetal and Ketal Isomers of Glycerol. Acta Chem. Scand. 1965, 19, 920-930. [CrossRef]

44. Kulkarni, R.M.; Arvind, N. Acetalization of glycerol and benzaldehyde to synthesize biofuel additives using $\mathrm{SO}_{4}{ }^{2-} / \mathrm{CeO}_{2}-\mathrm{ZrO}_{2}$ catalyst. Heliyon 2021, 7, e06018. [CrossRef]

45. Li, R.; Song, H.; Chen, J. Propylsulfonic acid functionalized SBA-15 mesoporous silica as efficient catalysts for the acetalization of glycerol. Catalysts 2018, 8, 297. [CrossRef]

46. Pirez, C.; Caderon, J.-M.; Dacquin, J.-P.; Lee, A.F.; Wilson, K. Tunable KIT-6 Mesoporous Sulfonic Acid Catalysts for Fatty Acid Esterification. ACS Catal. 2012, 2, 1607-1614. [CrossRef] 